\title{
SENYAWA HASIL ISOLASI DARI TUMBUHAN KI ENCOK (Plumbago Zeylanica) YANG BERAKTIVITAS ANTIBAKTERI PENYAKIT MULUT DAN GIGI
}

\section{COMPOUNDS FROM KI ENCOK PLANT (Plumbago Zeylanica) AND THE ANTIBACTERIAL ACTIVITY OF DENTAL AND MOUTH DISEASE}

\author{
Euis Julaeha ${ }^{1}$, Tati Herlina ${ }^{1}$, Tri Mayanti ${ }^{1}$, Aditya Seiza Wibisono ${ }^{1}$, Riza Yulisar $^{1} \&$ Ajeng Diantini $^{2}$ \\ ${ }^{1}$ Departemen Kimia, Fakultas Matematika dan Ilmu Pengetahuan Alam, Universitas Padjadjaran \\ ${ }^{2}$ Fakultas Farmasi, Universitas Padjadjaran \\ Jl. Raya Bandung-Sumedang km. 21 Jatinangor, Sumedang, Jawa Barat 45363 \\ *Alamat Korespondensi: euis.julaeha@unpad.ac.id
}

\begin{abstract}
Abstrak: Plumbago zeylanica (Ki Encok) merupakan salah satu tumbuhan obat multifungsi yang banyak ditemukan di Indonesia. Daun dan akarnya berkhasiat sebagai obat pada berbagai penyakit termasuk anti jamur dan anti bakteri. Penelitian ini dilakukan untuk mengetahui senyawa bioaktif antibakteri yang dapat digunakan untuk mengobati penyakit gigi dan mulut. Dari hasil pemisahan dan pemurnann fraksi aktif, tiga senyawa telah

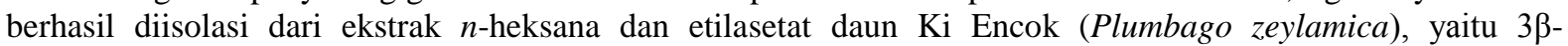
galaktosasitosterol (1), epi-isoshinanolon (2), dan metil 2,4-dihidroksibenzoat (3). Ketiga senyawa tersebut telah diuji aktivitasnya terhadap bakteri untuk penyakit mulut dan gigi yaitu Streptococcus mutan dan Streptococcus sanguinis. Hasilnya, diameter zona hambat dari senyawa 1, 2, dan 3 terhadap bakteri S. Sanguinis berturut-turut sebesar 12,0; 10,3; dan 12,0 mm, sedangkan terhadap bakteri $S$. Mutans berturut-turut sebesar 13,3; 11,7; dan $13,5 \mathrm{~mm}$.
\end{abstract}

Kata kunci: Ki Encok, Plumbago zeylamica, 3ß-galaktosa sitosterol, epi-isoshinanolon, metil 2,4dihidroksi benzoat, S. mutan dan S. sanguinis

\begin{abstract}
Plumbago zeylanica (Ki Encok) is a medicinal plant to have multifunction of pharmacological effect that found in Indonesia. The leaf and root of this plant showed activity including anti fungal and anti bacterial activities. The aim of this research is to find the active compounds that can be used as drugs for dental and mouth disease. From the result of separation and purification of active fractions, three compounds were isolated from n-hexane and ethyl acetate $K i$ Encok leaves (Plumbagozeylamica) extract. There are $3 \beta$ galactosesitosterol (1), epi-isoshinanolon (2), and methyl 2,4-dihydroxybenzoate (3). All compounds were tested for there activities against mouth and teeth bacterial diseases, namely Streptococcus mutants and Streptococcus sanguinis. The diameter of inhibition zone of compounds 1, 2 , and 3 of the bacteria S. sanguinis, respectively 12.0; 10.3; and $12.0 \mathrm{~mm}$, while the bacteria $S$. mutans of $13.3 ; 11.7$; and 13.5, respectively.
\end{abstract}

Keywords: Ki Encok, Plumbago zeylamica, 33-galaktosa sitosterol, epi-isoshinanolon, metil 2,4-dihidroksi benzoat, $S$. mutan dan $S$. sanguinis

\section{PENDAHULUAN}

Plumbago zeylanica merupakan salah satu tumbuhan obat multifungsi. Tumbuhan ini banyak ditemukan di wilayah Asia termasuk Indonesia. Masyarakat Indonesia lebih mengenal tumbuhan ini dengan nama Ki Encok. Nama ini berasal dari khasiat yang menurut kebanyakan masyarakat Indonesia secara turun temurun digunakan sebagai obat encok.

Daun dan akarnya berkhasiat sebagai obat pada berbagai penyakit diantaranya daun digunakan untuk obat encok atau rematik, masuk angin, susah buang air kecil dan sakit kepala (Syahid \& Kristina, 2008), menghilangkan rasa nyeri pada sendi (Alomet al., 2011), iritasi pada kulit (Alomet al., 2011; Shivanna \& Rajakumar, 2008), sakit perut (Ignacimuthu et al., 2006), menekan menstruasi (Yusuf et al., 2006) dan infeksi saluran kemih (Ahmad \& Beg, 2000). Secara etno farmakologi ekstrak akarnya memiliki aktivitas, anti-inflamasi, antifertil (Mandavkar \& Jalapure,
2011), antiseptik (Aladesanmi et al., 2007), antioksidan (Nile \& Khobragade, 2010), antifungi (Rahman\& Anwar, 2007), dan antibakteri (Jeyachandran et al., 2009; Vijayakumar et al., 2010).

Pada rangkaian penelitian kami telah diisolasi tiga senyawa dari ekstrak daun Ki Encok dan pada penelitian ini dilaporkan hasil uji aktivitas dari ketiga senyawa tersebut terhadap bakteri penyebab penyakit mulut dan gigi yaitu $S$. mutan dan $S$. sanguinis.

\section{BAHAN DAN METODE \\ Bahan dan Alat Penelitian Peralatan}

Isolasi senyawa dilakukan dengan menggunakan peralatan yang umum digunakan di Laboratorium Kimia Organik Jurusan Kimia FMIPA Unpad. 


\section{Bahan Tumbuhan}

Bahan tumbuhan berupa daun $\mathrm{Ki}$ Encok $(P$. zeylanica) diperoleh dari Lembang, Jawa Barat.

\section{Ekstraksi dan Isolasi}

Sampel daun ki encok ( $P$. zeylanica) dipotong kecil-kecil kemudian dimaserasi dengan methanol selama 3x24 jam, setiap hari filtrate ditampung. Filtrat selanjutnya dipekatkan dengan evaporator pada suhu $\pm 40^{\circ} \mathrm{C}$ hingga diperoleh ekstrak pekat. Ekstrak pekat dilarutkan dalam akuades, lalu dipartisi dengan $n$-heksana. Fraksi $n$-heksana ditampung kemudian sedangkan fraksi air dipartisi kembali dengan etil asetat.

Pemisahan dan pemurnian dilakukan dengan menggunakan berbagai teknik kromatografi, meliputi kromatografi kolom vakum, kromatografi kolom terbuka, kromatografi lapis tipis, dengan berbagai adsorben dan pelarut yang cocok, seperti yang umum dilakukan untuk isolasi senyawa kimia bahan alam.

\section{Uji Aktivitas Antibakteri Metode Kirby Bauer Peremajaan Bakteri}

Sebanyak satu ose bakteri $S$. mutans dan $S$. sanguinis dari stok diinokulasikan ke dalam tabung reaksi steril yang berisi suspense $\mathrm{NaCl}$ fisiologis sebanyak $4 \mathrm{~mL}$ hingga mencapai tingkat kekeruhan $1 / 2$ Mac Farland. Selanjutnya tabung reaksi kemudian diinkubasi selama $2 \times 16-18$ jam pada $37^{\circ} \mathrm{C}$.

\section{Uji Antibakteri terhadap Sampel, Kontrol Positif dan Negatif}

Kapas lidi dicelupkan dalam suspensi bakteri lalu dioleskan pada permukaan media agar hingga merata. Setelah itu sebanyak $50 \mu \mathrm{L}$ sampel, control positif (antibiotik) dan control negatif (metanol) diteteskan pada kertas samir (disk) kemudian diletakkan di atas media agar darah, lalu diinkubasi pada suhu $37^{\circ} \mathrm{C}$ selama $2 \times 24$ jam. Setelah $2 \times 24$ jam, diameter zona bening di sekitar sumur diamati dan diukur menggunakan jangka sorong.

\section{HASIL DAN PEMBAHASAN}

Dari daun ki encok ( $P$. zeylanica) disiapkan fraksi $n$-heksan dan fraksi etil asetat, kemudian diuji aktivitasnya terhadap salah satu bakteri penyebab penyakit mulut dan gigi yaitu $S$. sanguinis dengan tiga variasi konsentrasi yaitu 100, 1000, dan 10000 ppm. Kontrol positif yang digunakan adalah klorohexidin yang merupakan senyawa aktif terhadap bakteri $S$. sanguinis. Hasil pengujian ditunjukkan pada Gambar 1.

Dari Gambar 1 terlihat bahwa baik fraksi $n$ heksan maupun etil asetat menunjukkan hambatan terhadap pertumbuhan bakteri tersebut. Oleh karena itu, dilakukan isolasi senyawa terhadap kedua fraksi tersebut untuk mengetahui keberadaan senyawa aktif.

Dari kedua fraksi telah berhasil diisolasi senyawa 1 dari fraksi $n$-heksana, senyawa 2 dan 3 dari fraksi etil asetat yang teridentifikasi berturut- turut sebagai 3 $3 \beta$-galaktosasitosterol, epiisoshinanolon, dan metil 2,4-dihidroksibenzoat.

Selanjutnya dilakukan uji aktivitas terhadap ketiga senyawa tersebut terhadap bakteri $S$. sanguinis dan S. mutans, ditunjukkan pada Tabel 1.

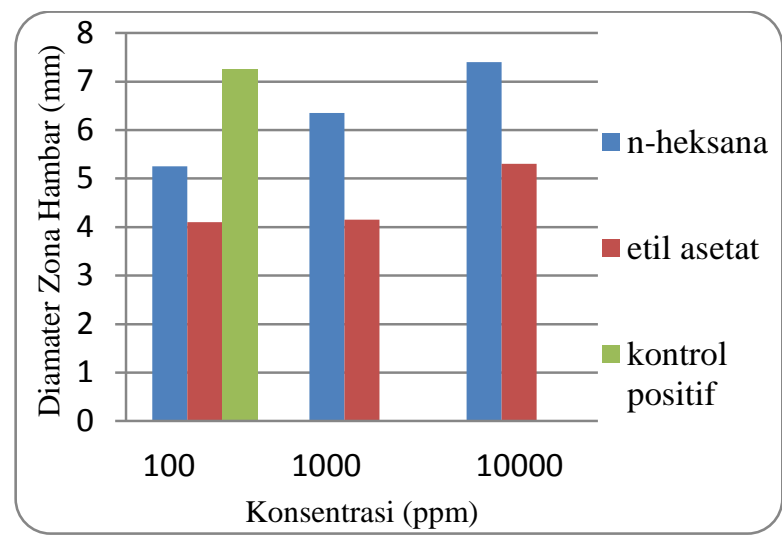

Gambar 1. Grafik hasil uji aktivitas antibakteri terhadap bakteri $S$. sangunis dari fraksi $n$-heksana dan fraksi etil asetat.

Tabel 1. Diameter zona hambat terhadap bakteri $S$. sanguinis dan S. mutans pada konsetrasi 1000 ppm

\begin{tabular}{ccc}
\hline \multirow{2}{*}{ Sampel } & \multicolumn{2}{c}{$\begin{array}{c}\text { Diameter zona hambat } \\
(\mathrm{mm})\end{array}$} \\
\cline { 2 - 3 } & S. sanguinis & S. mutans \\
\hline $\begin{array}{c}\text { Senyawa 1 } \\
\text { (3ß-galaktosa sitosterol) } \\
\text { Senyawa 2 }\end{array}$ & 12,0 & 13,3 \\
$\begin{array}{c}\text { (Epi-isoshinanolon) } \\
\text { Senyawa 3 }\end{array}$ & 10,3 & 11,7 \\
(metil 2,4-dihidroksibenzoat) & 12,0 & 13,5 \\
Kontrol negatif (DMSO) & 0 & 0 \\
Kontrol positif (Klorhexidin) & 18,4 & 20,4 \\
\hline
\end{tabular}

Dari Tabel 1 terlihat bahwa pada konsentrasi 1000 ppm semua senyawa dapat menghambat pertumbuhan baik bakteri $S$. sanguinis maupun $S$. mutans walaupun aktivitasnya lebih rendah dari standar sebagai kontrol positif klorhexidin.

\section{KESIMPULAN}

Fraksi $n$-heksana dan fraksi etil asetat daun $\mathrm{Ki}$ Encok ( $P$. zeylanica) menunjukkan hambatan terhadap pertumbuhan banteri $S$. sanguinis. Senyawa hasil isolasi dari kedua fraksi yaitu dari fraksi $n$ heksan 3 $\beta$-galaktosa sitosterol (1), fraksi etil asetat: epi-isoshinanolon (2), dan metil 2,4dihidroksibenzoat (3), juga menunjukkan aktivitas yang cukup tinggi baik terhadap $S$. Sanguinis maupun terhadap S. mutans.

\section{UCAPAN TERIMA KASIH}

Kami mengucapkan terima kasih kepada DP2M Dikti atas bantuan dana penelitian, Ketua Departemen Kimia Fakultas Matematika dan Ilmu 
Pengetahuan Alam, Universitas Padjadjaran, yang telah membantu dalam pelaksanan penelitian ini.

\section{DAFTAR PUSTAKA}

Ahmad, I. \& Beg, A.Z. (2000). Antimicrobial and phytochemical studies on 45 Indian medicinal plants against multi-drug resistant human pathogens. Journal of Ethnopharmacology 74: 113-123.

Aladesanmi, A.J., Iwalewa, E.O., Adebajo, A.C., Akinkunmi, E.O., Taiwo, B.J., F. O. Olorunmola, F.O. \& Lamikanra, A. (2007). Antimicrobial and antioxidants activities of some Nigerian medicinal plants. Afr. J. Trad. CAM.4(2): 173-184.

Alom, M.D., Zohora, F.T. \& Sultana, M. (2011). Ethnobotanical study of the Garo Tribe of Sherpur district, Bangladesh. J. Taxon. Biodiv. Res. 5: 39-42.

Ignacimuthu, S., Ayyanar, M. \& S.K Sivaraman, S.K. (2006). Ethnobotanical investigations among tribes in Madurai District of Tamil Nadu (India). Journal of Ethnobiology and Ethnomedicine. 2:25.

Jeyachandran, R., Manesh, A., Cindrella, L., Sudhakar, S. \& Pazhanichamy, K. (2009). Antibacterial activity of plumbagin and root extracts of Plumbago seylanica L, Acta Biological Cracoviensia Series Botanica 51(1): 17-22.

Nile, S.H. \& Khobragade, C.N. (2010). Antioxidant activity and flavonoid derivatives of Plumbago zeylanica. Journal of Natural Products. 3:130133.

Mandavkar, W.D. \& Jalalpure, S.S. (2011). A Comprehensive review on Plumbago zeylanica Linn. African Journal of Pharmacy and Pharmacology. 5(25): 2738-2747.

Rahman, M.S. \& Anwar, M.N. (2007). Antimicrobial activity of crude extract obtained from the root of Plumbago zeylanica. Bangladesh $J$ Microbial. 24(1): 73-75.

Shivanna, M.B. \& Rajakumar, N. (2010). Ethnomedico-botanical knowledge of rural folk in Bhadravathi Taluk of Shimoga District, Karnatakan. Indian Journal of Traditional knowledge. 9(1): 158-162.

Syahid, S.F. \& Kristina, N.N. (2008). Multiplikasit tunas, aklitimasi dan analisis mutu simplisia daun encok (Plumbago zeylanica L.) asal kultur

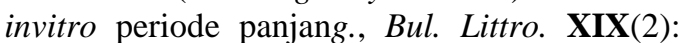
117-128.

Yusuf, M., Wahab, Md. A., Chowdury, J.U. \& Begum, J. (2006).Ethno-Medico-Botanical Knowledge From Kaukhali Proper and Betbunia of Rangamati District, Bangladesh J. Plant Taxon. 13(1): 55-61.

Vijayakumar, R, Latha, S., Sasikala, C., Srikumar, R., Thangaraj, R., Ayyappan, R., Jegadeesh, R. \& Hariprasath, L. (2010). Total phenolic content and antibacterial activity of various extracts of Plumbago zeylanica. Journal of Pharmacy Research. 3(10): 2442-2443. 